$1,2,3,4,5$

Department of Public Health Practice Institute Of Public Health, Lahore.

Correspondence address:

Dr. Rabia Arshed Usmani

Professor and Head,

Department of Public Health

Practice, IPH.

43, Sher Shah block, Garden

Town ,Lahore.

faryal_lhr@hotmail.com

Article received on:

17/02/2015

Accepted for publication:

15/09/2015

Received after proof reading

12/10/2015

\section{JOB SATISFACTION; AMONG DOCTORS WORKING IN PUBLIC AND PRIVATE TERTIARY CARE HOSPITALS OF LAHORE}

\section{Dr. Farah Deeba ${ }^{1}$, Dr. Rabia Arshed Usmani², Dr. Mahwish Akhtar ${ }^{3}$, Dr. Taskeen Zahra ${ }^{4}$,} Dr. Hafsa Rasool ${ }^{5}$

ABSTRACT... Background: Doctor's profession has been among one of the most attractive profession in Pakistan Society, but doctors are getting increasingly dissatisfied with their jobs in our region as unfortunately job satisfaction has still not received the proper consideration from policy makers. Objectives: To determine the level of satisfaction with variousjob characteristics and compare the characteristics of doctorswith level of job satisfaction among doctors working in public and private sector teaching hospitals. Study Design: Cross sectional study. Period: July 2014 to August 2014. Setting: Public sector (Jinnah Hospital Lahore) and a private sector (Fatima Memorial Hospital) Lahore. Methods: A total of 308 medical officers, 154 from each hospital were included through simple random sampling. They were interviewed regarding their socio demographic and work related characteristics and satisfaction level regarding various job characteristics, using a structured, pretested questionnaire. The job satisfaction was rated on the basis of a three point liker scale with scores ranging from $1-33$ and scores $\geq 25$ were considered as satisfied. All the data was entered and analyzed using SPSS version 17.0. Results: Among the total study respondents, majority 212 (68.8\%) doctor were dissatisfied with their jobs while high level of satisfaction was seen only regarding timeliness of pay $92.9 \%$ and job safety $98 \%$.On comparing characteristics of doctors with job satisfaction, it was seen that age, gender, marital status, number of family members, total family income, work experience and nature of job was not significantly related with satisfaction while doctors working in private hospital were more satisfied with their job as compared to doctors working in government hospital and this result was statistically significant $(P=0.000)$ Conclusion: Satisfaction level of doctors especially working in public hospitals was low as compared to doctors working in private sector. There is need to address the reasons of dis-satisfaction and formulate strategies to eliminate these issues.

Key words: Job satisfaction, public and private hospital, job characteristics

\section{INTRODUCTION}

Job satisfaction is a pleasurable or positive emotional state resulting from the appraisal of one's job or job experience. ${ }^{1}$ A person can be satisfied with one aspect of his or her job, like pay and dissatisfied with another aspect such as supervision. ${ }^{2}$ Career satisfaction among physicians should be paid great attention because they have a great impact on patient rated quality of care, physician work efficiency and at the same time on health-care costs. ${ }^{3-6}$

Recent Evidence suggests that physicians are becoming less satisfied with their jobs.A recent international study revealed that $49 \%$ of doctors believe they're not fairly compensated. This percentage increases to $54 \%$ among primary care physicians. ${ }^{7}$ Pakistani doctors are also increasingly getting dissatisfied with their jobs as unfortunately, in our region, job satisfaction has still not received the proper consideration from policy makers. About 80 doctors including 15 surgeons leave the country every year due to meager remuneration, inadequate resources of professional development and an overall discouragement of health profession in Pakistan. ${ }^{8}$ The aim of this study was to determine the level of satisfaction regarding individual job characteristics, overall job 
satisfaction and compare the characteristicwith overall level of job satisfaction of doctors working in public and private sector teaching hospitals.

\section{MATERIALS AND METHODS}

This cross sectional study was conducted from July 2014 to August 2014 in two tertiary care teaching hospitals viz. Public sector Jinnah Hospital Lahore and Private sector Fatima Memorial Hospital Lahore. Written Permission was obtained from hospital administration before conducting the study.A total of 308 medical officers and postgraduate trainees from seven major departments of each hospital were included in the study. About 154 doctors were recruited from each hospital and twenty two doctors from each department using simple random sampling technique. If any of selected doctor was absent during interview days, another doctor from same department, fulfilling the inclusion criteria was interviewed.Information was obtained regarding sociodemographic detail and satisfaction regarding various work related characteristics and noted in a semi-structured questionnaire. Data was entered and analyzed using SPSS version 17. The level of satisfaction was calculated for each of the 11 work related characteristic based on respondent's answers and scoring was done on three points Likert scale ( 1 =dissatisfied, $2=$ somewhat satisfied, $3=$ satisfied). The scores of all items were summed up to categorize broadly into satisfied (total score of 25 or more) and dissatisfied (total score of less than 25) and comparison was done with job characteristics. Chi square test was appliedtaking $p<0.05$ as statistically significant.

\section{RESULTS}

Job satisfaction is a worker's sense of achievement and success in the job and is directly linked to productivity as well as to personal well being. This study was carried out to determine and compare job satisfaction and work related characteristics in doctors working in public and private sector hospital in Lahore.

Table I shows the level of satisfaction of doctors with individual job characteristics which depicts that majority of doctors were highly satisfied with only 2 characteristics i.e. timeliness of pay 286 (92.9\%) and job safety 302 (98\%). However, major proportion of doctors reported somewhat satisfaction or dissatisfaction with job dimensions like work load, amount of pay, cooperation of hospital, guidance provided by senior, working environment, personal security at workplace, pleasure with job, career making opportunities and facilities at work place.Regarding overall job satisfaction, it was found on the basis of the total score that majority 212 (68.8\%) doctors were dissatisfied and only 96 (31.1\%) doctors were satisfied with their job.

Table II shows relationship of characteristics of doctors with job satisfaction. It can be seen that job satisfaction was more in doctors working in private hospital $91(94.8 \%)$ as compared to the public hospital $5(5.2 \%)$ andthis difference was statistically significant $(p=0.000)$. It was also seen that majority of the doctors with age less than 30 years $(36.9 \%)$, females $(34.5 \%)$, unmarried $(68.6 \%)$, family members less than $4(47.2 \%)$, family income less than 50,000 PKR (33.3\%), and total work experience of less than 5 years (34.9\%) were satisfied with their job. However, relationship of age, gender, marital status, number of family members, total family income, work experience and nature of job with overall level of job satisfaction was not statistically significant.

\section{DISCUSSION}

Job satisfaction is a crucial determinant of quality of health care provided by the physicians and results from complex interactions between on-thejob experience, organizational environment, and motivation. ${ }^{9,10}$ An important finding of this study was that majority $68.8 \%$ of the doctors were dissatisfied with their job while only $31.1 \%$ showed job satisfaction. Moreover, it was seen in this study that 'high satisfaction' was seen in only two job characteristics i.e. timeliness of pay and job safety as majority of the doctors in this study were permanent employees. Dissatisfaction and somewhat satisfaction was seen maximum regarding personal security at the work place followed by amount of pay, facilities at work place, cooperation of hospital management, guidance provided 


\begin{tabular}{|c|c|c|c|c|c|c|}
\hline \multirow{3}{*}{ JOB CHARACTERISTICS } & \multicolumn{6}{|c|}{ LEVEL OF SATISFACTION } \\
\hline & \multicolumn{2}{|c|}{ Highly Satisfied } & \multicolumn{2}{|c|}{ Somewhat Satisfied } & \multicolumn{2}{|c|}{ Not Satisfied } \\
\hline & No. & $\%$ & No. & $\%$ & No. & $\%$ \\
\hline Work Load & 24 & 7.8 & 238 & 77.3 & 46 & 14.9 \\
\hline Amount of pay & 17 & 5.8 & 205 & 66.6 & 86 & 27.9 \\
\hline Timeliness of pay & 286 & 92.9 & 19 & 6.2 & 3 & 1.0 \\
\hline Cooperation of hospital management & 24 & 7.8 & 215 & 69.8 & 69 & 22.4 \\
\hline Guidance provided by seniors & 87 & 28.2 & 181 & 58.8 & 40 & 13.0 \\
\hline Working environment & 41 & 13.3 & 232 & 75.3 & 35 & 11.4 \\
\hline Job safety & 302 & 98.0 & 3 & 1.0 & 3 & 1.0 \\
\hline Personal security at workplace & 1 & 0.3 & 181 & 58.8 & 126 & 40.9 \\
\hline Pleasure with job & 47 & 15.3 & 211 & 68.5 & 50 & 16.2 \\
\hline Career making opportunities & 99 & 32.1 & 176 & 57.2 & 33 & 10.7 \\
\hline Facilities at work place & 1 & 0.3 & 234 & 76.0 & 73 & 23.7 \\
\hline \multicolumn{7}{|c|}{$\begin{array}{l}\text { Table-I. Level of satisfaction of doctors with job characteristics }(n=308) \\
\text { *Scoring for Level of satisfaction: Highly satisfied }=3 \text {, Somewhat satisfied }=2 \text {, } \\
\text { Not satisfied }=1\end{array}$} \\
\hline \multirow{3}{*}{ CHARACTERISTIC } & \multicolumn{4}{|c|}{ JOB SATISFACTION* } & & \\
\hline & Satisfied & $=96)$ & Dissatisf & $n=212)$ & & \\
\hline & No. & $\%$ & No. & $\%$ & No. & $\%$ \\
\hline $\begin{array}{l}\text { Age } \\
\quad<30 \text { years } \\
>30 \text { years }\end{array}$ & $\begin{array}{l}45 \\
51\end{array}$ & $\begin{array}{l}36.9 \\
27.4\end{array}$ & $\begin{array}{c}77 \\
135\end{array}$ & $\begin{array}{l}63.1 \\
72.5\end{array}$ & $\begin{array}{l}122 \\
186\end{array}$ & $\begin{array}{l}39.6 \\
60.4\end{array}$ \\
\hline $\begin{array}{l}\text { Gender } \\
\text { Male } \\
\text { Female }\end{array}$ & $\begin{array}{l}48 \\
48\end{array}$ & $\begin{array}{l}28.4 \\
34.5\end{array}$ & $\begin{array}{c}121 \\
91\end{array}$ & $\begin{array}{l}71.6 \\
65.5\end{array}$ & $\begin{array}{l}169 \\
139\end{array}$ & $\begin{array}{l}54.9 \\
45.1\end{array}$ \\
\hline $\begin{array}{l}\text { Marital Status } \\
\text { Married } \\
\text { Unmarried }\end{array}$ & $\begin{array}{l}61 \\
35\end{array}$ & $\begin{array}{l}23.7 \\
68.6\end{array}$ & $\begin{array}{c}196 \\
16\end{array}$ & $\begin{array}{l}76.3 \\
31.4\end{array}$ & $\begin{array}{c}257 \\
51\end{array}$ & $\begin{array}{l}83.4 \\
16.6\end{array}$ \\
\hline $\begin{array}{l}\text { Number of total family members } \\
\quad<4 \\
>4\end{array}$ & $\begin{array}{l}50 \\
46\end{array}$ & $\begin{array}{l}47.2 \\
22.8\end{array}$ & $\begin{array}{c}56 \\
156\end{array}$ & $\begin{array}{l}52.8 \\
77.2\end{array}$ & $\begin{array}{l}106 \\
202\end{array}$ & $\begin{array}{l}34.4 \\
65.6\end{array}$ \\
\hline $\begin{array}{l}\text { Total Family Income } \\
<50,000 \text { PKR } \\
>50,000 \text { PKR }\end{array}$ & $\begin{array}{c}4 \\
92\end{array}$ & $\begin{array}{l}33.3 \\
31.1\end{array}$ & $\begin{array}{c}8 \\
204\end{array}$ & $\begin{array}{l}66.7 \\
68.9\end{array}$ & $\begin{array}{c}12 \\
296\end{array}$ & $\begin{array}{c}3.6 \\
96.4\end{array}$ \\
\hline $\begin{array}{l}\text { Type of Hospital** } \\
\text { Public } \\
\text { Private }\end{array}$ & $\begin{array}{c}5 \\
91\end{array}$ & $\begin{array}{c}3.2 \\
59.1\end{array}$ & $\begin{array}{c}149 \\
63\end{array}$ & $\begin{array}{l}96.8 \\
40.9\end{array}$ & $\begin{array}{l}154 \\
154\end{array}$ & $\begin{array}{l}50.0 \\
50.0\end{array}$ \\
\hline $\begin{array}{l}\text { Total work experience } \\
\leq 5 \text { years } \\
>5 \text { years }\end{array}$ & $\begin{array}{c}89 \\
7\end{array}$ & $\begin{array}{l}34.9 \\
13.2\end{array}$ & $\begin{array}{c}166 \\
46\end{array}$ & $\begin{array}{l}65.1 \\
86.8\end{array}$ & $\begin{array}{c}255 \\
53\end{array}$ & $\begin{array}{l}82.8 \\
17.2\end{array}$ \\
\hline $\begin{array}{l}\text { Nature of job } \\
\text { Permanent } \\
\text { Contract }\end{array}$ & $\begin{array}{l}68 \\
28\end{array}$ & $\begin{array}{l}25.8 \\
62.2\end{array}$ & $\begin{array}{c}195 \\
17\end{array}$ & $\begin{array}{l}74.2 \\
37.8\end{array}$ & $\begin{array}{c}263 \\
45\end{array}$ & $\begin{array}{l}85.4 \\
14.6\end{array}$ \\
\hline $\begin{array}{l}\text { Table-II. Characte } \\
\text { *job satisfactic } \\
\text { Total Score } \geq\end{array}$ & $\begin{array}{l}=\text { Sum of } \\
25 \text { taken as }\end{array}$ & $\begin{array}{l}\text { ors in rela } \\
\text { ore of eac } \\
\text { tisfied anc } \\
\text { value }=0\end{array}$ & $\begin{array}{l}\text { ndividual jo } \\
\text { core }<25 \\
0\end{array}$ & $\begin{array}{l}\text { ction }(\mathrm{n}= \\
\text { aracteristic } \\
\text { satisfied. }\end{array}$ & & \\
\hline
\end{tabular}


by the senior, working environment, pleasure with job and career making opportunities. Studies conducted in Hyderabad, Rawalpindi, Islamabad and Karachi also showed similar results in which $23.8 \%, 43.9 \%, 41 \%$ and $32 \%$ of the doctors were satisfied with their jobs respectively. ${ }^{11,14}$ Sultana et $\mathrm{al}^{12}$ found that only $44 \%$ of doctors were satisfied with the work load and $66.6 \%$ showed satisfaction with working environment whereas satisfaction with working environment was even low 51\% in study conducted by Kumar and collegues. ${ }^{13}$ Doctors working in Karachi also showed dissatisfaction with working hours, career opportunity and work load along with the amount of pay given to them. ${ }^{14} \mathrm{~A}$ study conducted at Bahawalpur showed that $56 \%$ doctors were not satisfied with the level of their income and $92 \%$ of all the doctors were neither satisfied with the present service structure nor with the career prospects in Pakistan. ${ }^{15}$ However, the study conducted by Qamar et al in different hospitals of Peshawar showed a higher job satisfaction $70.8 \%$ but the sample size of the study is quite less as compared to the sample size used in this study. ${ }^{16}$ Thus it can be seen that majority of the doctors all over in Pakistan showed a high level dissatisfaction with their job and job characteristics.

On comparing these figures with the job satisfaction in other countries, it was seen that similar levels of job satisfaction were seen in health workers of Uganda in which only $48.7 \%$ showed satisfaction while dissatisfaction was highest regarding working conditions and compensation. ${ }^{17}$

Similarly, German and Swiss physicians also showed dissatisfaction regarding hours of working, working condition and income. ${ }^{18,19}$ It was found that five job characteristics were given highest importance overall regarding job satisfaction i.e. good working relationship and physical conditions, training opportunities, tools to use skill in job and opportunity to advance. ${ }^{10}$ Income status, motivation by managers and colleague, stable job along with superior subordinate communication are also found to be major determinants of job satisfaction in various studies. ${ }^{20-23}$ Thus job satisfaction is found to be multidimensional and the current study showed a high proportion of dissatisfaction in all these job related aspects which resulted in overall job dissatisfaction. However, higher job satisfaction rates were found in studies conducted in developed countries like Canada and USA physicians in which overall job satisfaction was reported by $75.5 \%, 74 \%$ and $81 \%$ of the doctors respectively. ${ }^{24-26}$ While the mean score of job satisfaction scale were quite high in British, Australian and Lithuanian medical practitioners showing a wide variation from the present study. ${ }^{27-29}$

On comparing the sociodemographic and work related characteristic of the doctors with level of satisfaction it was found that doctors above the age of 30 years, having less than 4 total members of family, work experience of less than five years and having a permanent job were more satisfied with their jobs.Similar trends were seen in a survey conducted in UK which showed that young doctors were less satisfied with their jobs as compared to the old doctors. ${ }^{30}$ Moreover, it was seen that only few of the doctors having a total family income of less than 50,000 PKR per month was satisfied with their job. This further supports the finding that amount of pay is a major determinant of job satisfaction. Another important aspect highlighted by this study was high level of dissatisfaction in doctors working in public sector as compared to the private sector. These findings are also consistent with many other studies in which it was found that doctors working in private hospitals were more satisfied than public hospitals. ${ }^{10,16}$ No difference between public- and private-sector workers in overall Satisfaction was noted in Uganda but morale was higher in the private sector. ${ }^{17}$ The reason behind this is considered to be the multitier organizational setup of the public sector running on shoulders of many subdivision with problems in coordination while private sector although divided but have a closely coordinated working structure. ${ }^{20}$ Thus the doctors working in Pakistan shows quite similar picture all over in various studies regarding job satisfaction and a larger study is needed to be conducted on a more wider scale across the country to determine satisfaction with a greater external validity. 


\section{CONCLUSION}

The results of this study show dissatisfaction with job among doctors working in public and private hospitals thus an improvement in job conditions and characteristics especially the working environment, safety, work load and pay scale can lead to better satisfaction and motivation in the doctors.

Copyright(C) 15 Sep, 2015.

\section{REFERENCE}

1. Luthans F. Organizational Behavior. 9th ed. New York: McGraw Hill; 2002.

2. Job satisfaction is overall attitude. (Indian Express). (1998, December 27) Available:http://www.indianexpress.com/fe//daily/19981227/36155134.html.

3. Nikic D, ArandjelovicM, Nikolic M, Stankovic A. Job satisfaction in health care workers. ActaMedicaMedianae 2008; 47(4):9-12.

4. Wada K, Arimatsu M, Higashi T, Yoshikawa T, Oda S, Tanigochi $\mathrm{H}$ et all. Physician job satisfaction and working conditions in Japan. J Occup Health 2009; 51:261-266.

5. Landon BE, Reschovsky JD, Pham HH, Blumenthal D. Leaving medicine: The consequences of physician dissatisfaction. Med care 2006;44 :234-42.

6. Grembowski D, Paschane D, Diehr P, Katon W, Martin D, Patrick DL. Managed care, Physician job satisfaction and quality of primary care. J Gen Intern Med 2005; 20:271-7.

7. Physician compensation report. Medscape 2012. Available at http://www.medscape.com/features/slideshow/compensation/2012/public

8. The news. 2012. Available at: http://www.thenews.com. pk/Todays-News-2-123559-80-doctors-leave-countryevery-year.

9. Linzer M, BaierManwell L, Williams ES, et al. Working conditions in primary care: physician reactions and care quality. Ann Intern Med 2009;151:28-36.

10. Peters $\mathrm{DH}$, et al. Job satisfaction and motivation of health workers in public and private sectors: cross-sectional analysis from two Indian states. Human Resources for Health 2010; 8:27. Available at: doi:10.1186/1478-4491-8-27.

11. Sohag AA, Memon S, Mahmood-ur-Rahman, Rao $\mathrm{MH}$. A comparative study on factors causing job dissatisfaction among serving doctors at teaching hospitals of Hyderabad, Pakistan. Pak J Med Sci 2012;28(4):710715.

12. Sultana A, Riaz R, Hayat M, Sabir SA. Level of Job Satisfaction in Doctors. JRMC; 2009;13(2):95-97.

13. Kumar R, Ahmed A, Shaikh BT, Hafeez R, Hafeez A. Job satisfaction among public health professionals working in public sector: a cross sectional study from Pakistan. Human Resources for Health 2013, $11: 2$.

14. Khuwaja AK, Qureshi R, Andrades M, Fatmi Z, Khuwaja NK. Comparison of job satisfaction and stress among male and female doctors in teaching hospitals of Karachi. J Ayub Med CollAbottabad 2004; 16(1): 23-27.

15. Ghazali SSA, Shah IA, Zaidi SAA, Tahir MH. Job satisfaction among doctors working at teaching hospital of Bahawalpur, Pakistan. J Ayub Med Coll Abbottabad 2007; 19(3): 42-45.

16. Qamar FM, Baloch QB. Job satisfaction and performance: A comparative study of private and public sector hospitals. Abasyn J Social Sciences 2011; 4 (1): 56- 69.

17. Hagopian A, Zuyderduin A, Kyobutungi N, Yumkella F. Job satisfaction and morale in the Ugandan Health Workforce. Health Affairs 2009; 28(5) : w863-w875.

18. Goetz K, Musselmann B, Szecsenyi J, Joos S. The Influence of Workload and Health Behavior on Job Satisfaction of General Practitioners. Farm Med 2013; 45 (2): 95-101.

19. Bovier PA, Perneger TV. Predictors of work satisfaction among physicians. Eur j public health 2003; 13 : 299-305.

20. Kumari G, Pandey KM. Job Satisfaction in Public Sector and Private Sector: A Comparison. Inter J Innov Manage Tech 2011; 2 (3): 222-228.

21. Agyepong I, Anafi P, Asiamah E, Ansah EK, Ashon DA, Narh-Dometey C. Health worker (internal customer) satisfaction and motivation in the public sector in Ghana. International Journal of Health Planning and Management 2004; 19:319-336.

22. Dieleman M, Cuong PV, Anh LV, Martineau T: Identifying factors for job motivation of rural health workers in North Viet Nam. Human Resources for Health 2003, 5(1):10.

23. Leshabari MT, et al. Motivation of Health Care Workers in Tanzania: A Case Study of Muhimbili National Hospital. East African Journal of Public Health 2008; 


$$
\text { 5(1) : 32-37. }
$$

24. Lloyd S, Streiner D, Shannon S. Burn out, depression, life and job satisfaction among Canadian emergency physicians. J Emerg Med. 1994; 12: 559-65. [Crossref].

25. Bell DJ, Bringman J, Bush A, Phillips OP. Job satisfaction among obstetrician-gynaecologists: a comparison between private physicians and academic physicians. AMJ Obstet Gynecol. 2006; 195: 1474-8.

26. Petrozzi MC, Rosman HS, Nerenz DR, Young MJ. Clinical activities and satisfaction of general internists, cardiologists and ophthalmologists. J Gen Intern Med. 1992; 7: 363-5.

27. Taylor K, Lambert T, Goldacre M. Career destinations, job satisfaction and views of UK medical qualifiers of 1977. J R Soc Med. 2008; 101: 191-200.

28. Harris MF, Proudfoot JG, Jayasinghe UW, Holton $\mathrm{CH}$, Davies GPP, Amoroso CL, et al. Job satisfaction of staff and the team environment in Australian general practice. MJA 2007; 186: 570-3.

29. Puriene A, Petrauskiene J, Janulyte V, Balciuniene I. Factors related to job satisfaction among Lithuanian dentists. Stomatol Baltic Dent Maxillofac J. 2007; 9: 109-13.

30. Scott A, Gravelle H, Simoens S, Bojke C, Sibbald B. Job satisfaction and quitting intentions: a structural model of British general practitioners. British Journal of Industrial Relations 2006;44:519-40.

\begin{tabular}{|c|l|l|l|}
\hline \multicolumn{4}{|c|}{ AUTHORSHIP AND CONTRIBUTION DECLARATION } \\
\hline Sr. \# & \multicolumn{1}{|c|}{ Author-s Full Name } & \multicolumn{1}{|c|}{ Contribution to the paper } & Author=s Signature \\
\hline 1 & Dr. Farah Deeba & $\begin{array}{l}\text { Data interpretation, Final } \\
\text { approval } \\
\text { Data Analysis }\end{array}$ \\
\hline 2 & Dr. Rabia Arshad Usmani & Writing, Preparation \\
\hline 3 & Dr. Mehwish Akhtar & Manuscript editing \\
\hline 4 & Dr. Taskeen Zahra & Literature search, Data \\
\hline 5 & Dr. Hafsa Rasool & collection & \\
\hline
\end{tabular}

